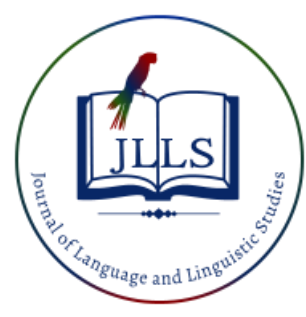

Available online at www.jlls.org

JOURNAL OF LANGUAGE AND LINGUISTIC STUDIES

ISSN: $1305-578 \mathrm{X}$

Journal of Language and Linguistic Studies, 17(3), 1277-1289; 2021

\title{
Conflict and ways of individualising mass images in early Kazakh prose
}

\author{
Kadisha R. Nurgali $^{\text {a } 1 \text { iD , Shynar B. Suleimenova }}{ }^{\text {b }}$ iD, Yuliya V. Bogdanovac ${ }^{\text {iD }}$ \\ ${ }^{a, b, c}$ L.N. Gumilyov Eurasian National University, Nur-Sultan, Republic of Kazakhstan
}

\section{APA Citation:}

Nurgali, K. R., Suleimenova, S. B., Bogdanova, Y. V. (2021). Conflict and ways of individualising mass images in early Kazakh prose. Journal of Language and Linguistic Studies, 17(3), 1277-1289. Doi: 10.52462/jlls.91

Submission Date:20/05/2021

Acceptance Date:25/08/2021

\begin{abstract}
Contemporary Kazakh prose is still experiencing the powerful influence of Auezov's artistic traditions. The paper reveals the importance of the early works of Mukhtar Auezov, in which the establishment of the main ideological, artistic and aesthetic qualities of Kazakh Soviet literature occurs at the initial stage with their subsequent deepening. The depth of insight into the inner spiritual world of a person, the scale in the sociohistorical reflection of reality, the skill in recreating the image of a person in prose - these signs of mature, artistic thinking were inherent in M. Auezov's early works. The scientific novelty of the paper is determined by the insufficient study of M. Auezov's early prose in these aspects. From the point of view of psychologism and the concept of person, the period of the 1930s in the works of M. Auezov differs significantly from the period of the 1920s. The portrayal of a new person actively building a socialist society, defending the homeland from class enemies, evolving morally and psychologically in the process of creating a new world, becomes the main task in Auezov's works in the 1930s. As the analysis of M. Auezov's works of the 1920s and 1930s reveals, the peculiarities of the development of his prose of these stages cannot be explained by the theory of evolutionary ascent from descriptiveness, psychologism to in-depth psychologism and mastery of psychological analysis.
\end{abstract}

Keywords: psychological analysis; aesthetic system; concept of person; author`s position; spiritual world

\section{Introduction}

Contemporary Kazakh prose is still experiencing the powerful influence of Auezov's artistic traditions. The depth of insight into the inner spiritual world of a person, the scale in the sociohistorical reflection of reality, the skill in recreating the image of a person in works - such signs of mature, artistic thinking were inherent in M. Auezov's early works. The stories and novels of $\mathrm{M}$. Auezov, published in the 1920 s, became evidence that a remarkable artist has appeared in the world of literature. In the view of this, the question regarding the predominant descriptiveness of the initial period in the history of Kazakh Soviet literature becomes more complicated.

\footnotetext{
${ }^{1}$ Corresponding author.

E-mail address: nurgali5596@uohk.com.cn
} 
The establishment of Mukhtar Auezov's (Figure 1) creative activities in the 1920s was largely associated with the solution of three interrelated epistemological and aesthetic problems, the first of which was the need to creatively assimilate and reinterpret the spiritual experience of national literature (folklore), therefore, Auezov's early work was characterised by a consistent and problematic appeal to the figure of a "batyr"; the second task consisted of the need for an extensive and in-depth study of the experience of more mature literature, primarily Russian classic works and Soviet, the assimilation of the advanced Marxist-Leninist theory, which became the basis of his worldview; the third task was the problem of large-scale comprehension of historical modernity, the social essence of historical changes in the Kazakh steppe, knowledge of the moral and psychological, spiritual world of the artist's contemporaries.

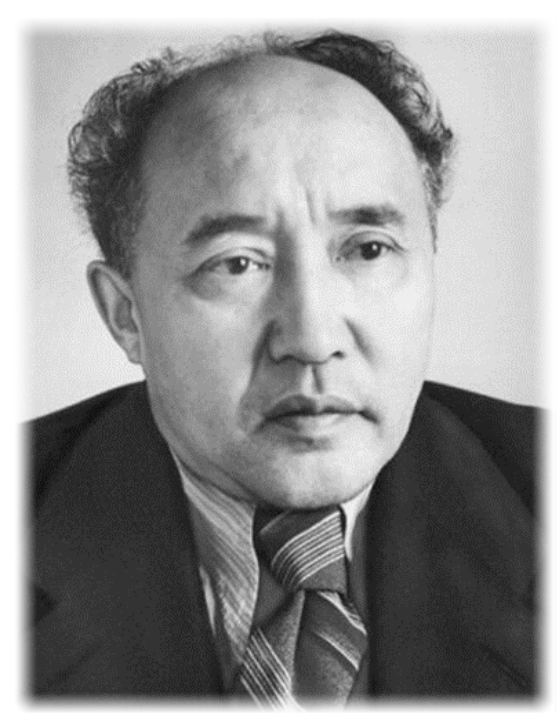

Figure 1. Mukhtar Omarkhanuli Auezov

Psychologism in the literature is not only its emotional and sensual element, what is usually called "infectiousness" or its immanent, generical property, psychologism in the work of a great artist is always holistic, manifesting itself both in content and in the form of a work, phenomenon. It reflects the entire depth of the author's thought on a person, the entire system of moral, ethical, sociopsychological criteria for determining his social value. In the works of literature scholars regarding the problem of artistic psychology, it is customary to distinguish between the concepts of psychology and psychological analysis. First, psychologism acts as a generic feature of the art of the word, its organic property, evidence of artistry. There is psychologism as a conscious and definite aesthetic principle. At the same time, it can be viewed as an organic unity of psychologism as an object and as a result of creativity (Aubakirova, 2015; Dautova et al., 2016).

The scientific novelty of the paper is determined by the insufficient study of M. Auezov's early prose in these aspects. The issues of Auezov's prose of the 1920s and 1930s, to one degree or another, were considered in dissertations devoted to the initial stage of Kazakh Soviet literature. As the analysis of M. Auezov's works of the 1920s and 1930s reveals, the peculiarities of the establishment of his prose of these stages cannot be explained by the theory of evolutionary ascent from descriptiveness, psychologism to in-depth psychologism and mastery of psychological analysis. It should be noted that we are talking about time scales within the above-mentioned decades. 


\section{Materials and Methods}

\subsection{The role of $M$. Auezov in the development of the principles of psychologism and establishment of psychological analysis}

Literature scholars point out that it has become almost generally accepted to consider a developed psychological analysis as a criterion for the literature maturity. There is merit in this point of view, but, apparently, with the proviso that in this case it refers to complex, higher forms of psychological analysis. Probably, the presence of some forms of psychological analysis in the earlier stages of the of literature development should not be depreciated, in particular, speaking of Soviet literature - the stages of its establishment. During this period of Soviet literature, such remarkable wordsmiths as M. Gorky, M. Sholokhov, L. Leonov, A. Fadeyev, and others successfully created their legacy (Auezova, 1975). Psychological analysis in the art of words is a form of knowledge and all types of cognition. It has undergone a long evolution. At the same time, if we talk about the initial stage of Kazakh Soviet literature, then it cannot be represented as the stage at which only descriptiveness and a simplified depiction of character prevailed. The novel of Mukhtar Auezov (1973) "Gunshot on the Mountain Pass", written in the 1920s, demonstrated a deep complex psychologism, mastery of psychological analysis, the author's keen understanding of the inner world of man. The material of this novel and some other works of this period indicates the place of psychological analysis in the artistic system of Auezov's prose of the 1920s, its aesthetic significance, as well as about its origins and directions of development, that is, to pose questions that are not fully covered in Kazakh literary criticism (Nurgali, 2010; Tahiri \& Muhaxheri, 2021; Omarova et al., 2020).

The material of other works of the same period, can serve as an object of analysis for the qualitative uniqueness of the embodiment of psychologism itself, understood as an emotionally expressive property of literature, and also as "a way of building an image, a way of reproducing, comprehension and evaluation of different life qualities. The category of psychologism in the art of words is closely related to such phenomena as the principles and means of depicting character, the author's concept of a person, etc. Psychologism as a complex aesthetic system in the works of M. Auezov becomes the basis for a holistic analysis and disclosure of such issues as the originality of his insight into the inner spiritual world of a person, features of the characteristics of the national outlook of the hero, the evolution of the concept of a person, the movement of narrative forms in Auezov's prose during the transition to new themes and heroes at the turn of the 1930s. Psychologism in the art of words is a complex dynamic category that permeates all the works of an author. Of particular importance for the study is the relationship of psychologism in M. Auezov's (1972) prose with the narrative fabric of works, with their architectonics, plot and compositional elements.

Psychological analysis is conditioned by generical psychologism, at the same time it differs from it, because psychological analysis is characterised by the qualities of thoughtfulness, purposeful organisation of its means, ideological emphasis on the main criteria for determining the sociopsychological essence of the hero. Psychological analysis expresses the author's desire to actively comprehend the world, breaking through the eternal questions of being, life and death, good and evil in the hero's soul, making his psyche, experiences and thoughts, as it were, the focus of the whole world. For the first time, the term "psychological analysis" was proposed by N.G. Chernyshevsky. Psychological analysis as an aesthetic system is significant not only for the depth of insight into the perceived world of the hero, but also for the special coherence, interaction of the means of reflecting this world. Psychologism and psychological analysis are in the same dialectical relationship as content and form in art, and their theoretical distinction is sometimes conditional, since in the works of developed word art, each side is present as an element of the whole. In terms of the deep and organic relationship of psychological analysis as an aesthetic category with the narrative structure of the work, 
researchers distinguish the following forms of it: types of internal and external speech of the hero, portrait, dialogue, landscape, actions and behaviour of the hero, author's psychological commentary, etc. Psychological analysis acts as the main "Means of character development" of his personal growth and self-realisation, if the dialectic of the image is present (Auezov, 1960; Altay et al., 2015; Zharylgapov et al., 2020).

The psychological analysis in the works of a true wordsmith is of a concrete historical, unique nature, because it is conditioned by the original author's concept of a person and reality, imbued with a special ideological and emotional tone characteristic to this writer. The uniqueness and originality of psychological analysis in the works of a particular wordsmith, it seems, should be in the field of view of a researcher who has put the problem of psychologism at the forefront of his research. Auezov's (1961) prose of the 1920s and 1930s is considered from the point of view of the development of aesthetic systems of psychologism and psychological analysis in it, the change of their components in accordance with the deepening of the author's concept of a person, conflict and problematics of works, as well as the influence of changes in psychology in different periods on the narrative of stories and novels (Akhmetov, 1977). In this problem, a certain place was taken by the coverage of the issue of M. Auezov's innovation in the field of developing the principles of psychologism and psychological analysis.

In the theory and history of literature, the issue of M. Auezov's innovation in improving the forms and principles of the psychological portrayal of the hero is studied insufficiently, in particular, the issue regarding peculiarities of the ideological and artistic role of folklore-epic motives and forms in depicting the appearance and inner world of the brave hero, Batyr. In the 1920s, traces of the influence of folklore were felt in the works of many Soviet writers (Badikov, 2014; Avsheniuk, 2019). Artists of the word often deeply reconsider the aesthetic experience of folklore and consciously use some of the features of its poetics in their works - this fact deserves close attention of researchers. The problem of ideological, aesthetic, historical and philosophical origins of psychologism in the writer's early prose, its development and enrichment are of great importance for the study of Auezov`s legacy. An important place in the study is occupied by the question of the distinctness of the psychologism embodiment in the prose of M. Auezov in the 1920s and 1930s, as well as the problem of the relationship and differences between psychological concepts and forms at the early stages of the writer's work (Issues of Kazakh Soviet literature..., 1957). Obviously, the 1920s was the time of the most profound ideological and artistic discoveries of M. Auezov in the field of psychologism, embodied by him in full-fledged artistic images. So, for example, in the 1920s M. Auezov achieves the dialectic of the image and the art of psychological analysis in the novels "Gunshot on the Mountain Pass", "Hard Times", in-depth psychologism in the novel "Beauty in Mourning" (Voronov, 1972; Omar, 2021).

\subsection{Conceptualisation of the figure of the "little man" in the works of M. Auezov}

Analysis of the collection of stories and the novel "Gunshot on the Mountain Pass" led to the conclusion that Mukhtar Auezov's appeal to the national literature experience (folklore), which he had associated with the typological problem of historical past of the Kazakh people, the life of the prerevolutionary mountain villages, did not mean an aesthetic absolutisation of its spiritual and pictorial values, idealisation of the "epic past". On the contrary, problematic, consistent comparison of "eternal" themes and "eternal" values with socio-historical reality allowed the writer to more deeply and more accurately understand the essence of modern events, socio-psychological nature of modern personality. Comparison of different times, their refraction in the psychological world, analysis of the complex contradictory struggle of opposing moral and ethical norms, attention to how the new intentions arise in the human soul, how he turns more and more decisively to a new life, in a painful 
inner struggle denies the old, obsolete, inert - all this testifies to the fact that the writer formed his concept of a new person; at the same time, it is essential that he understood - a new person will not come into this world ready, given in the integrity of his views, beliefs, inner world, the whole point is that a new person grows out of a person from the old society, grows up in a difficult, dramatic inner fight. In the man from the new society, the most diverse elements of the old and the new are bizarrely combined, and everything is in motion, evolution. Consequently, M. Auezov's appeal to the theme of the old pre-revolutionary village, is not accidental, it is dictated by deep ideological and artistic searches on the way of forming the concept of a new person. The humanist M. Auezov understood the vitality of the elements of the old in the psychological world, his attention to a person who is difficult and painfully going to the future, full of sympathy, full of understanding that in the new society many conflicts will be caused by the persistence of the old, the struggle of its forces for their positions. Therefore, the writer's attention to the conflicts that a disadvantaged, defenseless person enters into in the struggle for his dignity, the analysis of the social forces involved in the conflict, sympathy for the troubles of the "little man" have a deep positive meaning - this is the aesthetic basis that contributes to further ideological and artistic searches on the path of forming the concept of a new person - the builder of a new society (Smagulov et al., 2014).

Table 1. Concept of the "little man" in work of M.Auezov

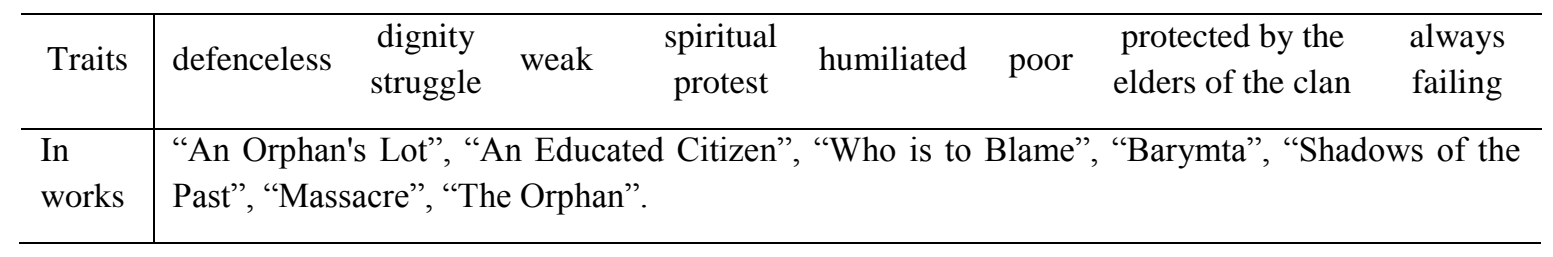

The sharpening of the conflict, its extreme dramatisation, the artistic solution of the conflict, sometimes as tragic for the "little man" - is a bridge on the way of the writer's transition from using traditional figures of Kazakh literature and its spiritually aesthetic experience to the image of a "humiliated, offended" person. Under the conditions of harsh reality, exceptional, extreme circumstances, a new person often turns out to be weak, defenseless, sometimes capable only of spiritual protest, tragic acts shown against the background of changing reality (destruction of familyfeudal relations, the onset of bourgeois ones), but the louder the writer's voice in his defense becomes, the larger is his humanism. The conflict, into which a disadvantaged, defenseless person enters with a hostile social environment, guilty of his troubles, appears as one of the constant and developing themes in the early work of M. Auezov. In a number of stories and novels written by the writer in the late 1920s and early 1930s, the focus is on the image of a dispossessed, humiliated person who often does not have sufficient strength to fight against oppressors, and protest only emotionally. The stories "An Orphan's Lot", "An Educated Citizen", "Who is to Blame", "Barymta", "Shadows of the Past", "Massacre", "The Orphan", and the story "Hard Times", the problem of cruel, heartless oppressors" violence over a weak, disadvantaged person serves as a kind of reflection of the main, central artistic conflict in the Kazakh literature of the 1920s - the conflict between the old and the new. This type of conflict was reflected in the stories and novels of B. Mailin "Monument to Shuge", "Kulpash", "Divorce", "Oath Zeynep", "Communist Raushan", in the story of S. Seifullin "Aisha", in stories by G. Mustafin "Blood", "Revenge", in the novel by G. Musirepov "In the Abyss", the story "Kos Shalkar", etc. (Auezov, 1973; Kukharchuk, 2018).

The distinctiveness of the main theme in the early works of M. Auezov was noticed by researchers. "Essentially, the main positive hero of Auezov's early work is a poor man, humiliated, dependent, sometimes cherishing the hope of getting protection and support from the elders of the clan, always failing at the same time, sometimes dying, but bravely defending his human dignity", writes E. 
Lizunova (1968). This problem - the problem of the "humiliated and insulted" in the early works of M. Auezov was at the center of the long-term polemic of literature scholars about the artistic method that Auezov adhered to in his early works. The controversy unfolded around Auezov's artistic interpretation of the image of the "little man". At the same time, it seems to us, in a whole group of works characteristic of M. Auezov's early works, the pathos of passionate denunciation of the dark forces of the past, its cruel laws, sympathy for the poor, disadvantaged people - victims of violence serve as the main argument for defining Auezov's early works as the works that used method of critical realism. "M. Auezov adhered to the method of critical realism, denounced the vices that are the product of the patriarchal-feudal Middle Ages ... But the lack of the writer's creativity lies in the fact that he limited himself only to exposure. Therefore, his defenseless characters appear to be truly defenseless" wrote T. Nurtazin (1957). A. Kaskabasov and E.D. Tursunov (1963); I. Dyusebaev (1974); T. Kakishev (1959) and other researchers consider the early works of M. Auezov as critical realism. A different point of view is expressed by E. Lizunova (1968), linking the early work of M. Auezov with "the peculiarities of the formation of socialist realism in its individual manifestation".

In opinion of the authors, the problem of the artistic method in the early works of M. Auezov is so complex that it requires further, special research. The variability of this problem lies in the fact that it is associated not only with the works of M. Auezov, but also with the peculiarities of the formation and development of the ideological and aesthetic qualities of Soviet literature at an early stage in general. Of particular importance for illuminating the issue of the artistic method in the works of Soviet writers of the early period is a concrete historical analysis of the peculiarities of the formation of the mastery of wordsmiths, insight into the specifics of the development of images, ideas, themes, forms in their works, consideration of the originality of the evolution of the author's concept of person and reality, the writer's worldview, etc. A holistic analysis of the works of Soviet writers of the early period, taking into account the largest possible number of parameters of the creativity of word artists in the aspect of their development and enrichment, would contribute to highlighting the problem.

\section{Results and Discussion}

\subsection{Analysis of the conflict and psychologism of M. Auezov`s early prose}

It seems that the analysis of the conflict and, accordingly, the psychologism of M. Auezov's early prose should be specific, with the possible full consideration of their features and interdependent connections. "An Educated Citizen" (1922) is one of the first stories by M. Auezov (1973). It mercilessly exposed the immoral essence of the bourgeois intellectuals Zhumagul and Aktay, and together with them, the young widow, woman from city Khadisha. Zhumagul uses his knowledge and scholarship for achieving a selfish goal - to take possession of the property of the widow, the wife of his recently deceased friend Maksut. Khadisha, for whom the role of a widow is painful, goes to meet Zhumagul's wishes. They unite their efforts, since the property remaining from Maksut legally belongs to his old mother. Aktai, who pursues his own selfish goals, helps them achieve their goals. The unhappy old woman seeks support from Meirkhan, a friend of her son, but her efforts lead nowhere. Social alienation of people, even relatives of close friends (Ospanova et al., 2014; Temirbolat et al., 2017).

The demise of traditional family ties amid the development of bourgeois relations in Kazakhstan, the disintegration of the former moral and ethical norms of life that developed in the depths of the patriarchal-clan system, one of which was the commandment to help orphans, old and lonely - this is the main theme of the story. The moral problem - the moral crime of young educated people in front of a disadvantaged old woman does not look accidental or abstractly humane. The conflict of the story "An Educated Citizen" is based on the internal ideological and semantic opposition of three different 
moral and ethical positions, which, as the author shows, adhere to the images-characters: patriarchalclan, bourgeois and democratic, expressed in the views of Meirkhan, the bearer of a positive principle. Exposure of essentially different moral positions is also based on showing different plans of people's life - urban and village (Kolesnikova et al., 2020; Garipova et al., 2019; Rusňák, 2018).

Developing the conflict of an artistic work, the author strives for a multifaceted, large-scale image of it, concretising and at the same time enriching the socio-psychological essence of the heroes, the direction of their actions and way of thinking. Moreover, a clear aesthetic tendency is the author's active interest not only in the image of the main character, the so-called "little man", but also in the images of negative heroes, grouped more often according to social characteristics, sometimes the author gives priority attention to these images, which is associated with the task of depicting them in detail. In the peculiarity of such a distribution of artistic attention, it is possible to see the writer's large-scale approach to the depicted conflict to characterise negative heroes, the author often resorts to identifying the voice of the people, popular opinion. Since ancient times, there has been a tradition in the Kazakh steppe, developed in the course of the millennial development of tribal relations - not to leave in trouble the lonely, disadvantaged, orphans, widows. This is how the institutions of adoption, levirate marriage, etc. were created. It is these traditions, calling for the protection of the lonely, humane and moral in nature, that have been abandoned as a result of the development of bourgeois relations. In many works of M. Auezov's, the voice of the people is intoned in the narrative structure, representing a generic moral and ethical position. The main events in the story "An Educated Citizen" are portrayed in the light of this position, this view, this is one of the ways to expose negative characters. People hoped that Khadisha and Zhumagul, having married, would not leave Maksut's orphaned mother in trouble. This point of view is intoned in the story, artistically and compositionally played up: "People wonder whether the newlyweds will bring an old woman with them. They should. She is now alone in the whole wide world, there is no one to look after the poor, and after all, she is the owner of all their wealth." With an ironic tinge, the author shows the unpretentious line of thought of Zhumagul's mother, who only formally pays tribute to the ancient moral and ethical tradition and who, in essence, is concerned only with one problem - to keep the old woman's goodness in her son's hands. And Kamaria, the mother of Zhumagul, thinks to herself: "It is unlikely that the old woman would have found a better son-in-law than my Zhumagul. He will feed her until the end of days. It is smart - to keep the young to herself. And it would be great to..." - Kamaria thinks to herself, but not a word out loud (Magsumov et al., 2019a).

The psychologism of the story "An Educated Citizen" is largely due to the originality of the conflict of the piece of work, in the focus of which the moral crime of Zhumagul and Khadisha is considered, the forms of the psychological characteristics of the heroes develop around the main moral and ethical situation. The narrative structure of the work is characterised by acute psychological situations, in which the hero's tests of morality are of particular importance. Such situations are distinguished by the author's especially keen attention to the hero, an active search for a string of humanity in him - this is a kind of provoking the hero for good, human responsiveness. These plot and compositional elements - test situations have a psychological aspect, they are aimed at exposing the most intimate in a person, essential for his socio-psychological characteristics. Such situations, repeating themselves, as if in stages determine the development of the main conflict of the story - the moral fall of the hero, and each time the appearance of such a situation in the plot means that the hope for the hero's revival is not lost. There are four main psychological situations in the story, these are the meeting of Zhumagul's eyes with Maksut's mother at the moment when the young, leaving the city, drive past the house, the meeting of Zhumagul and Khadisha with the people from village, the meeting of Zhumagul with Meirkhan, Maksut's friend after returning to the city, a clash of Zhumagul with an old woman during the confiscation of her property (Magsumov et al., 2019b; Ashilova, 2014). 
A feature of the socio-psychological characteristics of negative characters in M. Auezov's prose is that, as a rule, they are portrayed as a certain social group, with its inherent moral and psychological qualities. The writer seeks to characterise the group of negative heroes as a whole, united in the main aspect - cruelty towards the "little man" with all the insignificant individual qualities of each of the negative heroes. In most of M. Auezov's stories and novellas, negative characters are portrayed in a social group - they are either bourgeois intellectuals, or rich landowners with their servants, class enemies of the builders of a new society.

By resorting to the method of parallel characterisation of negative heroes, that is, to showing one through reasoning and the attitude of the first character towards him, when the first is also characterised, or to the method of showing negative heroes when they are all characterised in one situation, in one action as one social unity, the author depicts them against the background of popular opinion, popular attitude, acting as a moral criterion. At the same time, the writer resorts to such expressive means of depiction as irony, satire, mainly connecting ironic intonation with the voice of the people, with ruthless popular opinion and laughter. So, for example, ordinary village people very quickly guess the ordinary stupidity and arrogance of Zhumagul and Khadisha, disguised under the decent appearance of the educated townspeople.

The ridicule and judgement from common folk are an accurate, effective and unmistakable means of characterising negative heroes. The author's trust in the voice of the people and their opinion in the characterisation of negative heroes is associated with an understanding of the basic moral ideas of the people, their moral feeling, which does not forgive any violence against weak, defenseless people. Many stories and novels by M. Auezov are characterised by reproduction of the people's laughter, the people's voice, as the basic moral background, as the ultimate moral and ethical instance. If in the socio-psychological plane, the voice of the people, or elements of folk laughter serve as an unmistakable criterion for determining the social essence of negative heroes, the characteristics of their inner world, then in a more general aesthetic sense, the ever deeper understanding of the theme of the people and the artistic implementation of its image by M. Auezov in stories and novels testifies to the steady development and enrichment of the epic in his work.

The ideological and artistic role of the image of the three travelers in the story "The Orphan" is to a certain extent similar to the role of the figure of Meirkhan in the story "An Educated Citizen". Undoubtedly, the images of the three travelers are interpreted as carriers of a positive moral principle, for a traveler in the work of M. Auezov (1973) is a traditionally positive figure, symbolising moral movement, a person's knowledge of the world and the laws of life through actual movement along the road. In the aspect of this meaning of the images of the three travelers, the tragic situation in the story - the travelers find the corpse of a boy on the road - also acquires a symbolic meaning, movement forward, the development of the moral is impossible without experiencing the events of reality, everything tragic in life as their own, personal. For the psychologism of the story "The Orphan", it is not typical to deepen into the inner world of the hero. The psychology of the work is based on the drama of the main tragic situation - the conflict of an orphan-boy with cruel, soulless people who are ready to do anything for profit. The socio-psychological characteristic in the story unfolds mainly around the images of negative heroes, while such forms of psychological characteristics as the author's irony, elements of folk laughter, actions, actions and speech of the hero, psychologised landscape, etc. appear to be especially functional.

The story "Barymta" (1925) is one of the most picturesque, vivid and dynamic among the early works of M. Auezov (1973). The dynamics of the story is mostly event-driven: the actions and behaviour of the characters replace one another with cinematic speed, one event replaces another. With the skill of an outstanding artist, scenes of combat battles of "dzhigits" belonging to different tribes were painted. Each fragment of the story is full of dynamics that reflect the desperate struggle of 
large groups of people. The dynamism in the story is due to the dominance of the events in the plot, the characters of the heroes are drawn sketchily, the author does not set himself the task of a detailed psychological image of the hero's appearance, analysis of his inner world. But, as it seems, the psychologism of the work does not lose meaningfulness from this, because the narrative is organised in a complicated manner - the external event plan is opposed to the second plan, the subtext, in which the thought of the tragic absurdity, meaninglessness of the "heroic" deeds of horsemen who shed blood for an insignificant goal runs through it - to protect the interests of bai, the land owner (Polyakova \& Balanyuk, 2018).

The philosophical and psychological content of the narrative in the story "Barymta" is due to the internal comparison of two types of conflict: local (clash of tribes) and general, permanent (class antagonism between the poor and oppressive land owners). The two types of conflict depicted in the story are mutually reflective. The first type of conflict is introduced to the external plane of the narrative; its features are the transience of flashing events and their invariable tragedy in the consequences. As the author shows, the dynamism of this type of conflict, its frequent repetition, delay the solution of the main conflict - the class one. The aesthetic significance of this comparison lies in the denial of what is romanticised in the external image, taking into account the perception of the characters. This anti-aestheticist of external and internal in "Barymta" recalls the opposition of two aesthetic tendencies in the stories "Orphan's Lot", "Gray Fierce", the story "Gunshot on the Mountain Pass" (Auezov, 1973) - idealisation and de-idealisation of the hero (Mamadaliev et al., 2020).

Psychologism, embodied in the story "Hard Times" (Auezov, 1973), includes a phased multidimensional individualisation of the image of the people; the basic means of psychological depiction of both the mass of the people and the individual are developed in direct connection with this task. The principles of social and psychological differentiation of people are also enriched and deepened. To characterise negative heroes, the author uses folk laughter, folk accusatory intonation, various forms of external characteristics, speech, etc.

It seems that the multifaceted complex psychologism of the novel "Hard Times" was prepared by the writer's ideological and artistic searches, which were reflected in the stories "An Educated Citizen", "The Orphan", "Barymta", etc. The connection is found in many directions. It is obvious that the diverse forms of socio-psychological characteristics of negative heroes, embodied in the story, were "tested" in stories, and the tendency to represent negative heroes by social groups, to characterise them in total, in parallel.

\section{Conclusions}

This tendency can be interpreted as a kind of attempt at typification. It is expressed in the story in an extremely accurate, rational, cleared of ambiguities characterisation of negative characters, mainly through the forms of ridicule and sarcasm. The figure of the "little man" was of great importance on the path of enriching the psychologism of M. Auezov's prose, the broad, epic approach of the writer to the depicted reality. The harmoniously interconnected development in M. Auezov's prose of epic (wide coverage of events) and psychological (depiction of an individual) led him to artistic achievements, embodied in the story "Hard Times". An important role was played by the image of the "little man" in M. Auezov's prose and in creating the image of the people, for the writer sought to show the actions of the little man against the background of popular reaction - the people's sympathy for his troubles. From one piece of work to another, the writer complicated and enlarged the image of the people. In the story "Hard Times" he managed to achieve the image, both of the collective portrait of the people, and the refraction of the moral and psychological traits of the people in the guise of an individual personality. The forms of psychological characterisation and psychological analysis, 
embodied by M. Auezov in stories and novels of the 1920s, are diverse and unique: this is a psychologised landscape, types of internal and external speech of the hero, portrait details, psychological associations and retrospections, elements of folk laughter.

The criteria of in-depth psychologism in the art of writing, which can also indicate the presence of psychological analysis, can be a special consistency, unity and integrity in the organisation of forms of psychologised narration, means of socio-psychological characterisation of the hero, the dialectic of the image and the original, meaningful concept of man and reality, embodied in work. The psychological analysis is embodied in M. Auezov's novels "Gunshot on the Mountain Pass", "Hard Times", and the novel "Beauty in Mourning", written in the 1920s. In these works, the writer seeks to expose the inner complexly developing psychological world of the hero.

For the forms of psychological analysis in these works, a feature is inherent - they reflect the dynamism, processes of the hero's inner world. Another important feature of the forms of psychological analysis in these works is their bright coloration in the spirit of national artistic imagery, which is associated with the task of reflecting the national attitude, the characteristics of a hero close to the people. In the system of forms of psychological analysis of the hero's inner world, psychological antithesis, a psychologised landscape, psychological associations and retrospections, elements of the hero's inner speech, portrait details, actions of the hero, etc. are especially functional. A system of criteria for the socio-psychological differentiation of heroes has been developed: for example, negative heroes are depicted outside of connection with nature, mainly in actions and behavior, with the help of the author's commentary; often, to characterise them, the author resorts to elements of accusatory laughter. The positive hero, as shown in the works of M. Auezov, in extreme, sometimes tragic circumstances, manifests a protesting, rebellious beginning. Evolving self-awareness and the ability to comprehend reality most clearly characterise the positive hero.

From the point of view of psychologism and the concept of person, the period of the 1930s in the works of M. Auezov differs significantly from the period of the 1920s. The portrayal of a new person actively building a socialist society, defending the homeland from class enemies, evolving morally and psychologically in the process of creating a new world, becomes the main task in Auezov's works in the 1930s. The socio-psychological characterisation of the hero in Auezov's works of this period is carried out against the background of socialist labor. Labor is the main factor in the moral and psychological evolution of a person, changes in his inner moral image, outlook; at the same time, the attitude to work, the degree of its awareness as the basic necessity of a person in a new society is a clear criterion for determining the socio-psychological essence of the hero. Along with the theme of labor, the theme of the hero's life is distinct in the works of M. Auezov. At the same time, the gap between a person's behavior in everyday life and his actual role in production plays a characterising role, in particular with respect to the negative hero. The liberation of a person from the old way of life, from old habits, ethical prejudices is associated with the beginning of his spiritual evolution. The realities of everyday life and labor play an important role in the characterisation of the hero, appear as stylistic dominants in Auezov's work of the 1930s. In Auezov's works of the 1930s, the dynamics of the external, eventful prevails over the dynamics of the internal, psychological, - this corresponds to the author's concept of a new person - a person of action, struggle. Psychologism in Auezov's work of this period is mainly objectified.

\section{References}

Akhmetov, Z.A. (1977). Problems of studying the work of Mukhtar Auezov. Bulletin of the Academy of Sciences Kaz.SSR, 10, 14-23. 
Altay, A., Aituganova, S., \& Aubakirova, K. (2015). The main features of translations of foreign literature by Jusupbek aimautuly: Cultural and historical differences. American Journal of Applied Sciences, 12(12), 1023-1031.

Ashilova, M.S. (2014). Trends and challenges of educational system in the XXI century. Asian Social Science, 10, 225-231.

Aubakirova, K. (2015). Political and social reflection of post-colonial Kazakhstan in translations of American literature (On the basis of the works by Jusupbek Aimautuly and Jack London). Asian Social Science, 11(27), 8-17.

Auezov, M.M. (1972). Times a connecting thread. Alma-Ata: Zhazushy.

Auezov, M.O. (1960). Karash-Karash. Alma-Ata: KazGoslitizdat.

Auezov, M.O. (1961). Thoughts of different years. Alma-Ata: KazGoslitizdat.

Auezov, M.O. (1973). Short stories and tales of 1921-1947. Complete Works. Moscow: Khudozhestvennaya Literatura.

Auezova, L.M. (1975). Features of historicism epic M.O. Auezov "The Way of Abai". Vestnik AN Kaz.SSR, 4, 45-50.

Avsheniuk, N.M. (2019). Functional literacy development in the adult population: experience of Australia. Bulletin of Mukachevo State University. Series "Pedagogy and Psychology", 2(10), 201-204.

Badikov, V. (2014). With eternity - honestly. In Pushkin and Auezov (Eds). Analogies and approximations (pp. 282-285). Almaty: Alash.

Dautova, G.R., Sagyndykov, N.B., Abdikulova, R.M., Omirbayeva, T.S., \& Temirbolat, A.B. (2016). The meaning of the names and miraculous birth of epic heroes in the Turkic epics. Man in India, 96(10), 3917-3926.

Dyusebaev, I.T. (1974). Mukhtar Auezov. Alma-Ata: Nauka, 1974.

Garipova, V., Ayupova, R.A., \& Markova, E.M. (2019). Linguistic means of description of family relations in the novel In Chancery by J. Galsworthy. Journal of Research in Applied Linguistics, 10(Special Issue), 416-423.

Issues of Kazakh Soviet literature. (1957). Retrieved on Feb 19, 2021 from: http://online.pubhtm15.com/poge/movt/\#p=1.

Kakishev, T. (1959). Ideological and creative issues of Kazakh Soviet literature in the period of its formation (1917-1929). Alma-Ata: Kazakh Ablai Khan University of International Relations and World Languages JSC.

Kaskabasov, S.A., \& Tursunov, E.D. (1963). The heyday of Kazakh literature over the years of Soviet power. Alma-Ata: Znaniye.

Kolesnikova, S.M., Markova, E.M., Burskaya, E.A., \& Chibisova, A.V. (2020). Concept of "family" in the Russian and Chinese linguoculture: Cognitive, phonosemantic and educational aspects. Asia Life Sciences, 22(2), 229-242.

Kukharchuk, O.S. (2018). Cultural connections of the Transcarpathian people with the population of Ukrainian regions: literacy, birth of historic knowledge, education. Bulletin of Mukachevo State University. Series "Pedagogy and Psychology", 1(7), 29-33. 
Lizunova, E.V. (1968). The skill of Mukhtar Auezov. Alma-Ata: Zhazushi.

Magsumov, T.A., Nizamova, M.S., Artemova, S.F., \& Allalyev, R.M. (2019a). The Akhal-Teke expeditions of 1879-1881 years: Historical and statistical study. Part 1. Bylye Gody, 53(3), 12561262.

Magsumov, T.A., Nizamova, M.S., Ponomareva, M.A., \& Allalyev, R.M. (2019b). The Akhal-teke expeditions of 1879-1881 years: Historical and statistical study. Part 2. Bylye Gody, 54(4), 17541760.

Mamadaliev, A.M., Allalyev, R.M., Miku, N.V., \& Médico, A. (2020). The Japanese armored cruisers and mine-torpedo forces of the opposing sides during the Russian-Japanese war. Bylye Gody, 55(6), 295-333.

Nurgali, R. (2010). Kazakh literature: concepts and genres. Astana: Foliant.

Nurtazin, T. (1957). Issues of development of Kazakh literature of the 20s. In the book: Collection of articles on Kazakh literature. Alma-Ata: KazGoslitizdat.

Omar, A. (2021). Identifying themes in fiction: a centroid-based lexical clustering approach. Journal of Language and Linguistic Studies, 17, 580-594.

Omarova, A., Kaztuganova, A., Sultan, Y., Turmagambetova, B., \& Ryskaliyeva, G. (2020). Creativity of Zhambyl Zhabayev in the context of integration processes. Opción, 36(Special Edition 27), 188-201.

Ospanova, A., Temirbolat, A., Abdikulova, R., Mekebaeva, L., Kalkabaeva, S., \& Ospanova, A. (2014). The idea of Turkic unity in Kazakh poetry of the early twentieth century. Life Science Journal, 11(8), 207-211.

Polyakova, L.G., \& Balanyuk, L.L. (2018). The black sea province in the first world war: A historiographical review. Bylye Gody, 48(2), 838-849.

Rusňák, R. (2018). Bolest' a smrt' v minimalistických textoch literatúry pre deti v slovenskom preklade. Bulletin of Mukachevo State University. Series "Pedagogy and Psychology", 2(8), 207211.

Smagulov, Z.K., Kalybekova, K.S., Takirov, S.U., Babashov, A.M., Aubakirov, N.M., Kenzhegaliyev, S.A., Nurzhanova, K.K., \& Zhumageldin, Z.S. (2014). Sh. Ualikhanov and theories of mythological school in Russian literal study. Life Science Journal, 11(9 Spec. Issue), 202-206.

Tahiri, L., \& Muhaxheri, N. (2021). Linguistic criticism of the interior monologue in fiction. Journal of Language and Linguistic Studies, 17, 899-910.

Temirbolat, A.B., Imakhanbet, R.S., Orda, G.Z., Ospanova, A.A., \& Omarov, T.K. (2017). Specifics of embodiment of the national idea in Kazakh literature. Man in India, 97(20), 435-445.

Voronov, V. (1972). Faces of folk life. Moscow: Sovetskiy pisatel'.

Zharylgapov, Z., Rustemova, Z., Takirov, S., Kenzhegaliev, S., \& Beisentai, A. (2020). Typology of realism and Kazakh literary studies. Opcion, 36(Special Edition 26), 39-56.

\section{AUTHOR BIODATA}

Kadisha R. Nurgali is a Full Doctor in Philology, Professor, Head of the Department of Russian Philology, L.N. Gumilyov Eurasian National University, Nur-Sultan, Republic of Kazakhstan. She is the author of 4 
monographs, 4 textbooks and more than 100 scientific and literary critical articles about literature theory, history of Russian literature, concept of man and history in Kazakh prose, works of Anur Alimzhanov and others.

Shynar B. Suleimenova is a Master of Philology, Doctoral Student, Department of Russian Philology, L.N. Gumilyov Eurasian National University, Nur-Sultan, Republic of Kazakhstan. She is the author of more than 30 publications about language for special purposes, English History, basic research, language for academic purposes. She participated in international and national conferences and seminars.

Yuliya V. Bogdanova is a Master of Philology, Lecturer, Department of Russian Philology, L.N. Gumilyov Eurasian National University, Nur-Sultan, Republic of Kazakhstan. 